\title{
O Corpo Épico: Dança
}

Quando decidimos formar um grupo, decidimos trabalhar juntos para pesquisar a formulação do "Teatro Hip-Hop". Uma linguagem requer referências e estamos ainda em processo de formulações de conceitos. A cada montagem, galgamos mais um passo nessa ambiciosa empreitada. Cada objeto de estudo foi se apresentando: a singularidade da palavra para o ator-MC, a interpretação épica e dramática, o corpo e seu gestus, que dança ao pulso da cena. Vou discorrer um pouco, aqui, sobre este "corpo épico" de nossa pesquisa que, sem dúvida, no espetáculo Orfeu Mestiço, alcançou uma potência maior do que um dia vislumbrávamos.

Utilizo, aqui, a expressão "corpo épico" para ir ao encontro do raciocínio da nossa pesquisa, buscando conceitualizar nosso anseio em desenvolver no princípio do simbólico da dança uma função narrativa.

Minha escrita será do ponto de vista deste "corpo épico", que dança nessa linguagem, até o resultado de Orfeu Mestiço.

\section{A jornada}

Quando a Claudia Schapira convidou o Eugênio Lima para a montagem de Bartolomeu, o que será que nele deu? (2000) era por reconhecer a potência que a 'Unidade Móvel', na época a companhia dirigida por ele, alcançava com sua dança. Sentia ser uma linguagem urbana capaz de moldar toda a movimentação da peça.

O Eugênio tinha a mão forte de diretor e criador de movimento. Naquele começo, foi fundamental toda a sua disciplina de coreógrafo e preparador para mergulharmos nesse universo. Foi nossa primeira "enciclopédia" da cultura Hip-Hop. Assistíamos aos clipes e filmes, preenchendo nosso imaginário com os gestos dessa cultura. Jogávamos basquete, utilizando suas jogadas como táticas de cenas. Fazíamos, diariamente, um circuito de exercícios físicos e dançávamos, dançávamos muito. 
Com essa profunda e genuína vivência, em nossa segunda montagem, Acordei que Sonhava (2003), percebemos a necessidade de uma manutenção para continuidade da pesquisa, introduzindo em nosso cotidiano o treinamento de ioga, que até hoje nos acompanha.

Ao mesmo tempo que levantávamos a peça, realizávamos o projeto Urgências nas Ruas, uma série de intervenções pelo centro de São Paulo. Por ter uma dinâmica de criação rápida, performática, as ações nas ruas nos deixaram com um corpo desperto e comunicativo.

Como sempre comentamos, o espetáculo Acordei que Sonhava foi nosso levante. Nosso corpo aqui, tanto quanto a palavra, afirmava sua presença dentro dessa linguagem.

Após essas três experiências, entramos num processo que necessitava acolher um pouco o que havíamos vivido para colher mais tarde. Mergulhamos ainda mais na raiz dos quatro elementos do hip-hop (DJ, MC, Grafite e B.Boy), e para o corpo coube estudar e estruturar mais a técnica da dança de rua.

Tivemos aula com o dançarino Frank Ejara, um dos mais reconhecidos dançarinos e ativo pensador da cultura hip-hop no Brasil, que nos trouxe referências da dança de rua e seus estilos, desde as danças sociais dos anos 70 às técnicas de breaking, popping, locking, nas quais fomos rastreando a história dos passos e tateando nosso corpo nesse movimento.

Nosso objetivo sempre foi que a dança virasse gesto e o gesto virasse dança. Creio que no espetáculo Fratria Amada Brasil (2006), chegamos em movimentos coreográficos, principalmente nos coros que percorriam todo o espaço ao redor do público, compondo o movimento da cidade e seu pulso. Imagem em ação. Fotogramas dançados da cidade.

Tivemos, ainda, mais cinco peças em 2008: $3 \times 3$ - 3 DJs em busca do vinil perdido, Encontros Notáveis, Manifesto de Passagem, Vai te Catar! e Cindi Hip-Hop. Cada uma, com sua particularidade, deixou para o coletivo a maturidade para navegar na Pajelança de Kuarup de Congá, projeto inicial que daria origem à montagem de Orfeu Mestiço, a nossa hip-hópera.

\section{Orfeu Mestiço}

Em Orfeu Mestiço (2011), literalmente dançamos, bailamos, flutuamos entre as tradições das danças, tanto das que havíamos estudado como das que cada artista trazia em 
si. Capoeira, maracatu, afro e as danças brasileiras em geral, tendo sempre a dança de rua contornando a movimentação, criando momentos de total explosão de linguagem nos quais, como numa pintura, não se consegue distinguir qual o primeiro 'traço-gesto' originado.

No início desse processo focamos muito na teoria, pois eram muitos conceitos para estruturar a narrativa que desejávamos: o olhar para trás na formação do povo brasileiro. Num caminho paralelo, o corpo seguia com um treinamento que utilizava técnicas da ashtanga vyniasa yoga como base, e assim que compreendemos que o mito do Orfeu seria nosso ponto de partida, começamos uma trajetória dançada das ações dessa sinopse. Cada artista foi responsável por levantar uma parte do mito. Como não estávamos utilizando a palavra, a movimentação se deu de forma a introduzir o coro em uma ação protagonista da narrativa cênica. Nesse exercício, chegamos a imagens potentes, poéticas e que, por vezes, ilustravam; por outras, criavam um universo onírico que esbarrava num cotidiano vulgar. Por exemplo, o estraçalhamento de Orfeu era dançado ao som de um liquidificador triturando um alimento.

Quando chegou às nossas mãos nosso libreto hip-hoperístico, começamos a parte mais focada de todo esse processo: levantar cuidadosamente cada parte deste caleidoscópico texto. Nesse momento, os quatro integrantes do núcleo tiveram que dispor do seu melhor e de suas melhores referências para dar ação às fortes palavras dessa narrativa-dançada-cantada. Coube a mim, além de ser atriz, dar atenção especial ao movimento e às coreografias.

"Samplear" uma música, uma imagem, um texto - e até nós mesmos - é uma das estratégias de nossa criação. Portanto, a cada cena as demandas apareciam, e com um claro direcionamento por parte da direção (o pulso firme da diretora Claudia Schapira), traçávamos alguns rascunhos coreográficos, desenhando as ações.

O foco na direção do corpo em cena, seja numa coreografia ou mesmo numa simples movimentação, sempre foi o pulso. Pulsar junto, comunicando uma ação coletiva, vibrando com suas individualidades e qualidades de movimento. Nosso prólogo do Orfeu é a tentativa na direção de nos apresentarmos como um coletivo dissonante.

(link do prólogo - "sou eu sou eu" - 00:05:41 até 00:07:41)

Quase sempre a música era o que dava ação ao corpo, como é o caso da dança ao redor de Eurídice, que coreografei assim que a batida se deu, e rapidamente se moldou ao coro, formado pelo coletivo "Treme Terra", que executou com total brilhantismo e propriedade. 
(link dos meninos entrando dançando no Círculo em volta de Eurídice - 00:12:06 até 00:14:01)

Outro bom entendimento da busca da dança como gesto da ação é na movimentação do jantar, onde tudo acontece em sincronia. Ao mesmo tempo que é uma ação cotidiana - um jantar numa farta mesa envolta pelos serviçais - os giros dos bancos vão esclarecendo as relações tensas dos personagens, e os 'movimentos-cacos' dos empregados junto com o Griot e os sons, comentam os climas.

(Link do jantar - 01:10:36 até 01:13:57)

São muitos momentos de expansão dessa pesquisa em Orfeu, mas creio que a explosão de imagem coreográfica nessa montagem se dá num dos momentos ápices da peça, que é o estraçalhamento: Orfeu mais velho cai, e Orfeu jovem faz o papel hermético de encaminhar a história com uma música que transita entre Kuduro e drum'n'bass. As "erínias" entram dançando num passo da dança afro, que vai sendo invadido pela imagem das moiras esticando os seus "fios-cabelos", enquanto ao centro acontece uma dança tipicamente break.

(link dança do estraçalhamento II - 01:44:34 até 01:46:46 )

O "corpo épico" dança pra comunicar, ressignificar e comentar as ações. É um corpo que se assume mestiço em sua manifestação, e que age no impulso de dizer.

Creio que a proximidade histórica da montagem ainda nos deixa um pouco míopes para compreender o real resultado estético desta obra dentro da nossa linguagem. O que me fica neste porto de chegada é a liberdade com a qual perambulamos no universo da dança, sem querer decodificar literalmente o "como", mas sim celebrar o "o que." Como diz Pina Bausch “Dancem, dancem... senão, estamos perdidos”. 